\title{
Thyrotoxic pretibial myxoedema in Asian patients in Singapore
}

\author{
C. W. KeE \\ M.B.B.S.
}

J. S. CHEAH

F.R.A.C.P.

\section{Department of Medicine (Unit 1), University of Singapore, Singapore}

\begin{abstract}
Summary
Over a 5-year period, three cases of thyrotoxic pretibial myxoedema were encountered. The incidence of pretibial myxoedema in Chinese thyrotoxic patients in Singapore was $0.7 \%(0.3 \%$ in females and $1.6 \%$ in males). One of the three patients also had thyroid acropachy. The incidence of thyrotoxic pretibial myxoedema in Singapore is compared with that in the literature and the aetiology briefly reviewed.
\end{abstract}

Pretibial myxoedema is an unusual complication of thyrotoxicosis and there is scanty knowledge of its incidence. Gimlette (1960) reported an incidence of $4.3 \%$ while Shasky and Nelson (1966) found an incidence of $1 \%$. There has been no previous report of the incidence of thyrotoxic pretibial myxoedema in Asians or in the tropics. This paper describes the incidence of pretibial myxoedema in Singapore over a 5 -year period and the clinical features observed.

\section{Materials and methods}

There were 479 cases of thyrotoxicosis seen in the Department of Medicine (Unit I), University of Singapore, over a 5-year period, 1968-1972. Of these, 322 were female and 157 were male. There were 435 Chinese, thirty-one Malays, six Indians and seven of other ethnic groups. Pretibial myxoedema was carefully looked for in all cases and it was found in three Chinese (diagnosis confirmed by skin biopsy). Two of these were male, giving an incidence of $1.6 \%$ of 129 Chinese thyrotoxic males, and one was female, giving an incidence of $0.3 \%$ of Chinese thyrotoxic females. The overall incidence of pretibial myxoedema in Chinese thyrotoxic patients, male and female, was $0.7 \%$. In addition, two of the patients had diffuse thickening of the skin and subcutaneous tissues but skin biopsies were not diagnostic; these two cases are excluded from the study. The three cases are reported in detail below.

\section{Case reports}

Case 1

A 47-year-old Chinese male storekeeper was seen

Correspondence: Dr J. S. Cheah, Medical Unit I, Outram Road General Hospital, Singapore 3, Republic of Singapore. for weight loss with increased appetite, sweating and tremors of the hands. Clinically, he was thyrotoxic. The thyroid gland was twice normal size, soft and smooth. He had bilateral exophthalmos (Grade 1, American Thyroid Association Classification; Werner, 1969). There was no clubbing of the fingers or toes. His basal metabolic rate (Dubois) was $+50 \%$ (normal $\pm 15 \%$ ) and the radioiodine ${ }^{131} \mathrm{I}$ ) uptake by the thyroid gland at $4 \mathrm{hr}$ was $67 \%$ and at $24 \mathrm{hr}$ was $62 \%$ (normal $15-40 \%$ ). He was treated with carbimazole $15 \mathrm{mg}$ four t.i.d. for 2 months, after which he developed an allergic rash. He was then given $5 \mathrm{mCi}$ of ${ }^{131} \mathrm{I}$ followed by potassium perchlorate 4 months later as he was still clinically thyrotoxic, but this was discontinued after 2 months, when he became euthyroid.

Fifteen months later, he relapsed. The thyroid uptake of ${ }^{131} \mathrm{I}$ at $4 \mathrm{hr}$ was $43 \%$ and at $24 \mathrm{hr}, 49 \%$. At this stage, he was noted to have bilateral circumscribed swellings over both shins. Skin biopsy of one of the swellings over the shin confirmed the diagnosis of pretibial myxoedema; there was separation of the collagen fibres probably due to interstitial oedema and mucinous degeneration of some fibres. Thyroid antibodies (tanned red cell agglutination) were positive $1: 25$, and antimicrosomal antibodies were positive. The serum immunoglobulins were IgG $1520 \mathrm{mg} / 100 \mathrm{ml}$ (normal 598-1086 mg/100 ml; Chew, $\mathrm{Yu}$ and Wee, 1969); IgA $130 \mathrm{mg} / 100 \mathrm{ml}$ (normal 91-399 $\mathrm{mg} / 100 \mathrm{ml}$ ) and IgM $26 \mathrm{mg} / 100 \mathrm{ml}$ (normal 44-100 mg/100 ml). He was then treated with carbimazole for another 4 months; his pretibial myxoedema remained unchanged.

\section{Case 2}

A 55-year-old Chinese man presented with congestive cardiac failure. He was found to be thyrotoxic. His thyroid gland was twice normal size and was firm and nodular and he had Grade 1 bilateral exophthalmos. There was no clubbing of the fingers or toes. The resin uptake of triiodothyronine was $195 \%$ (normal $75-115 \%$ ) and his total serum thyroxine was $12 \cdot 3 \mu \mathrm{g} / 100 \mathrm{ml}$ (normal 3-7 $\mu \mathrm{g} / 100 \mathrm{ml}$ ). He was then treated with carbimazole, $15 \mathrm{mg}$ four t.i.d., digoxin and diuretics. Two weeks later, he developed multiple, nodular swellings over both his 
shins. Skin biopsy of one of the skin nodules showed increased mucopolysaccharides in the dermis with small infiltrations of chronic inflammatory cells (mainly lymphocytes) occurring especially around the sweat glands and blood vessels. The histological findings were consistent with pretibial myxoedema. Thyroid antibodies (tanned red cell agglutination) and antimicrosomal antibodies were negative. His serum immunoglobulins were: IgG $3200 \mathrm{mg} / 100 \mathrm{ml}$; IgA $280 \mathrm{mg} / 100 \mathrm{ml}$; IgM $86 \mathrm{mg} / 100 \mathrm{ml}$. With treatment of his thyrotoxic state with carbimazole, his pretibial myxoedema became more severe.

\section{Case 3}

A 59-year-old Chinese housewife presented with thyrotoxicosis with Grade 2 bilateral exophthalmos. The thyroid gland was three times the normal size and was firm and nodular. The thyroid uptake of ${ }^{131}$ I was $76 \%$ at $4 \mathrm{hr}$ and $71 \%$ at $24 \mathrm{hr}$. The patient was treated with carbimazole for 20 months-this failed to control the thyrotoxicosis. She was then given a dose of $12 \mathrm{mCi}$ of ${ }^{131} \mathrm{I}$, and was maintained on carbimazole for another 2 years. She remained thyrotoxic and was again given ${ }^{131} \mathrm{I}$, in a dose of $7.9 \mathrm{mCi}$. Following this second dose she became euthyroid. Two years later, she complained of nodular swellings over her shins and feet and hoarseness of voice. Clinically, she was hypothyroid. Her exophthalmos became more severe. She had multiple firm nodular swellings over both her lower legs and feet as well as mild clubbing of her fingers. Her cardiorespiratory system was normal. Her resin uptake of triiodothyronine was $71 \%$ with a total serum thyroxine of less than $1.6 \mu \mathrm{g} / 100 \mathrm{ml}$. Her IgG was 1040 $\mathrm{mg} / 100 \mathrm{ml}$ (normal 683-1152 mg/100 ml), IgA 60 $\mathrm{mg} / 100 \mathrm{ml}$ (normal $197-386 \mathrm{mg} / 100 \mathrm{ml}$ ) and IgM 43 $\mathrm{mg} / 100 \mathrm{ml}$ (normal $56-98 \mathrm{mg} / 100 \mathrm{ml}$ ). There were no antithyroid antibodies (tanned red cell agglutination) or antimicrosomal antibodies. The skin biopsy of one of the swellings showed the dermis containing markedly increased acid mucopolysaccharides.

Chest X-ray showed no lung lesions and the heart was enlarged. X-rays of hands showed severe osteoporotic changes and X-rays of feet showed some periosteal reaction in the metatarsals.

\section{Discussion}

There have been few reports on the incidence of pretibial myxoedema in thyrotoxic patients. In America, Shasky and Nelson (1966) mentioned an incidence of $1 \%$, while Gimlette (1960) had found an incidence of $4.3 \%$. Gimlette estimated a true incidence of $5 \%$; he was of the opinion that mild cases of pretibial myxoedema may occur at the onset or soon after the appearance of other symptoms of thyrotoxicosis and either before or after treatment of the thyrotoxic state. In these cases, the lesions are said to be transient and to regress spontaneously. In his series, severe cases occurred only after treatment of hyperthyroidism and were associated with severe exophthalmos. Greer (1957) stated that localized pretibial myxoedema is relatively rare and appears during active hyperthyroidism or after treatment of the disease.

Kriss (1964), on the other hand, found that none of the pretibial myxoedema in his patients preceded or coincided with the onset of thyrotoxicosis but that in all of them it developed after treatment of the thyrotoxicosis. The temporal relationship between the thyrotoxic state and the appearance of pretibial myxoedema would appear to be variable as one patient in the present series developed the lesions only 2 weeks after treatment with carbimazole while the remaining two developed the lesions after treatment with ${ }^{131}$ I. All these lesions corresponded to those described by Gimlette (1960) and Warthins and Boshell (1957). The more severe form, in which the skin is elephantiasis-like (Gimlette, 1960; Warthins and Boshell, 1957; Shasky and Nelson, 1966), was not seen in the present series. Gorman (1972) stated that it is rare to see pretibial myxoedema in a patient without ophthalmopathy, and Warthins and Boshell (1957) thought that pretibial myxoedema may herald the onset of malignant exophthalmos.

All three patients in the present study had bilateral exophthalmos but none progressed to the malignant stage. Thyroid acropachy was seen in one patient with exophthalmos, pretibial myxoedema, clubbing and periosteal thickening of the metatarsals (case 3). The aetiology of pretibial myxoedema in thyrotoxicosis is not known. Gimlette (1960) noted that the severe cases of pretibial myxoedema tended to occur in patients whose thyrotoxic state was readily reversible, since they became hypothyroid with treatment of the thyrotoxic state. Case 3 became hypothyroid after treatment with two doses of ${ }^{131} \mathrm{I}$.

Warthins and Boshell (1957) postulated that rapid reversion from the hyperthyroid state to the euthyroid state may be a factor precipitating pretibial myxoedema. He also found that injection of triiodothyronine into the pretibial myxoedema lesions of one of his patients resulted in a temporary disappearance of the lesions; he concluded that the area of pretibial myxoedema is a true area of local hypothyroidism owing to the insensitivity of local tissues to active thyroid hormone.

In several studies (Kriss, Pleshakor and Chein, 1964; Shasky and Nelson, 1966; Beighton, 1968), the level of long acting thyroid stimulator (LATS) was found to be high in patients with pretibial myxoedema. LATS is known to be abnormal immunoglobulin in the IgG fraction (Kriss et al., 1964; Shasky and Nelson, 1966) and is thought to be an antibody with humoral properties (Shasky and Nelson, 1966). 
Kriss et al. (1964) postulated that the destruction of the thyroid gland by disease (hyperthyroidism or thyroiditis) or by therapeutic agents (especially ${ }^{131} \mathrm{I}$ ) results in the release of an antigen of thyroid cell origin which then stimulates the production of the antibody, LATS. The antibody is then fixed to the tissues of the legs, the phenomenon being facilitated by a number of factors such as dependency of the lower limbs, trauma, vascular injury, cardiac failure, exposure to cold or hypothyroidism. The resulting immunological reaction then causes a local inflammatory tissue reaction which manifests as pretibial myxoedema. It is therefore interesting to note that two of our patients had elevated levels of IgG. Although the levels of LATS were not determined in these patients, the high level of IgG would support an immunological mechanism underlying the pathogenesis of pretibial myxoedema. In this context, it is significant that pretibial myxoedema has also been found in patients with Hashimoto's thyroiditis (Peard, 1961) and myxoedema with lymphocytic infiltration of the thyroid gland (Haydar, 1963). There may therefore be a common factor which induces inflammatory changes in the thyroid gland as well as causing exophthalmos, pretibial myxoedema and clubbing.

\section{References}

BeIghton, P. (1968) LATS activity, exophthalmos and digital clubbing associated with myxoedema. Postgraduate Medical Journal, 44, 426.
CheW, B.K., YU, M. \& WeE, R. (1969) Immunoglobulin levels in four ethnic groups in Singapore. Far East Medical Journal, 5, 98.

Gimlette, T.M.D. (1960) Pretibial myxoedema. British Medical Journal, ii, 348.

GreER, M.A. (1957) Exophthalmos and localised pretibial myxoedema in a euthyroid patient. Journal of Clinical Endocrinology and Metabolism, 17, 1466.

Gorman, C.A. (1972) Unusual manifestations of Graves' Disease. Mayo Clinic Proceedings, 47, 926.

HAYDAR, N.A. (1963) Exophthalmos, digital clubbing and pretibial myxoedema in thyroiditis. Journal of Clinical Endocrinology and Metabolism, 23, 215.

Kriss, J.P., Pleshakor, V. \& Chein, J.R. (1964) Isolation and identification of the long acting thyroid stimulator and its relation of hyperthyroidism and circumscribed pretibial myxoedema. Journal of Clinical Endocrinology and Metabolism, 24, 1005.

LeVer, W.F. (1961) Histopathology of the Skin, 3rd edn, p. 353. J. B. Lippincott Co., Philadelphia and Montreal.

Peard, M.C. (1961) Lymphadenoid goitre with hypothyroidism, exophthalmos, pretibial myxoedema and acropachy. Proceedings of the Royal Society of Medicine, 54, 342.

Shasky, D. \& Nelson, J. (1966) Pretibial myxoedema. Archives of Dermatology, 94, 658.

Warthins, T.A. \& Boshell, B.R. (1957) Pretibial myxoedema. American Medical Association Archives of Internal Medicine, 100, 319.

Werner, S.C. (1969) Classification of the eye changes of Graves' disease. Journal of Clinical Endocrinology and Metabolism, 29, 982.

\title{
Autoimmune haemolytic anaemia and ulcerative colitis
}

\author{
D. W. Gorst \\ M.A., B.M., B.Ch., M.R.C.P. \\ M. J. LEYLAND
M.R.C.P. \\ I. W. Delamore \\ Ph.D., F.R.C.P.Ed., M.C.Path. \\ University Department of Clinical Haematology, Royal Infirmary, Manchester
}

\begin{abstract}
Summary
Two cases of ulcerative colitis are described in which there was associated severe auto-immune haemolytic anaemia. The colitis in both patients responded to conventional therapy and one patient underwent splenectomy for her anaemia. Possible aetiological links are discussed.
\end{abstract}

ANAEMIA is a common accompaniment of ulcerative colitis. It is usually due to gastro-intestinal blood loss or to marrow depression with impaired release of reticulo-endothelial iron associated with chronic inflammation.

The association of ulcerative colitis and autoimmune haemolytic anaemia has been described, but 